\title{
Epigallocatechin-3-gallate combined with alpha lipoic acid attenuates high glucose-induced receptor for advanced glycation end products (RAGE) expression in human embryonic kidney cells
}

\author{
JYH-GANG LEU ${ }^{1,2}$, CHIN-YAO LIN ${ }^{2}$, JHIN-HAO JIAN ${ }^{3}$, CHIN-YU SHIH $^{4}$ and YAO-JEN LIANG ${ }^{3}$ \\ ${ }^{1}$ Fu-Jen Catholic University School of Medicine, Nº 510 Zhongzheng Road, Xinzhuang Dist, New Taipei City 24205, Taiwan \\ ${ }^{2}$ Division of Nephrology, Department of Internal Medicine, \\ Shin Kong Wu Ho-Su Memorial Hospital, No. 95 Wen Chang Road, Shih Lin District, Taipei 11101, Taiwan \\ ${ }^{3}$ Department and Institute of Life Science, Fu-Jen Catholic University, \\ No. 510 Zhongzheng Road, Xinzhuang Dist, New Taipei City 24205, Taiwan \\ ${ }^{4}$ Department of Animal Pharmacology, Development Center for Biotechnology, \\ No. 101, Lane 169, Kanging St. Xizhi District, New Taipei City 22160, Taiwan
}

Manuscript received on march 8, 2012; accepted for publication on December 17, 2012

\begin{abstract}
The anti-oxidant effects of epigallocatechin gallate (EGCG) and alpha lipoic acid (ALA) have been demonstrated in previous studies. The kidney protection effects of EGCG and ALA in patients with kidney injury are still under investigation. The purpose of this study is to investigate the anti-inflammatory and anti-oxidant effects of EGCG and ALA on high glucose-induced human kidney cell damage. EGCG inhibited high glucose(HG)-induced TNF- $\alpha$ and IL-6 production in human embryonic kidney (HEK) cells. Both EGCG and ALA decreased HG-induced receptor of advanced glycation end products (RAGE) mRNA and protein expressions in HEK cells. EGCG and ALA also recovered HG-inhibited superoxide dismutase production and decreased ROS expressions in HEK cells. The synergism of EGCG and ALA was also studied. The effect of EGCG combined with ALA is greater than the effect of EGCG alone in all anti-inflammation and anti-oxidant experiments. Our studies provide a potential therapeutic application of EGCG and ALA in preventing progression of diabetic nephropathy.
\end{abstract}

Key words: diabetic nephropathy, receptor of advanced glycation end products, epigallocatechin gallate, alpha lipoic acid, anti-oxidant.

\section{INTRODUCTION}

Diabetic nephropathy is the leading cause of endstage renal disease in most developed countries (Ansari et al. 2003). The clinical manifestations include increased glomerular filtration rate, microalbuminuria, macroalbuminuria, and renal failure. The pathological changes include glomerular basement membrane thickness, mesangial expan-

Correspondence to: Yao-Jen Liang

E-mail:071558@mail.fju.edu.tw sion, glomerular sclerosis, and interstitial fibrosis (Mauer et al. 1984). High serum glucose levels in diabetic patients may stimulate angiotensin II (AT-II), various inflammatory substances, and superoxide production in kidney cells; augment inflammatory reaction; destroy normal kidney cells and induce fibrosis formation (Jiao et al. 2011). ATII may enhance oxidative damage, cell apoptosis, and necrosis by producing ROS through the NADH/ NADPH oxidase system (Watanabe et al. 2010). 
Oxidative stress has recently been proposed as the major damaging factor in hyperglycemia (Giugliano et al. 1996). Apoptotic cell death associated with increased oxidative stress in organs of diabetic patients has been well documented (Yang et al. 2011). However, the effect of anti-oxidant therapy in diabetic patients is still under investigation.

Advanced glycation end products (AGEs) is the products of nonenzymatic glycation and oxidation of proteins and lipids in diabetic patients. AGEs has been speculated to play a key role in the pathogenesis of diabetic nephropathy (Bohlender et al. 2005). The cellular effects of AGEs are mediated by specific receptors, one of which is the receptor for AGE (RAGE). RAGE is a transmembrane receptor of the immunoglobulin superfamily, expressed on the cell surface of several circulating and organ-specific cells, including monocytes, macrophages, proximal tubular cells, podocytes, and mesangial cells (Sourris et al. 2010). Recent studies showed that RAGE is a multiple ligand receptor. The ligand families of RAGE includes AGEs, advanced oxidation protein products, S100/calgranulins, highmobility group box-1, amyloid- $\beta$ peptide, and $\beta$-sheet fibrils. In diabetic patients, hyperglycemia may stimulates the production of these ligands and activate RAGE, the consequent signaling pathways, and inflammatory reaction (Yan et al. 2010). Oxidative stress and $\mathrm{NF}-\kappa \mathrm{B}$ have been shown to play major roles in kidney and vascular damage induced by RAGE activation (Yamagishi 2011, Yan et al. 1994).

Epigallocatechin-3-gallate (EGCG) is the main and most significant polyphenol in green tea. Numerous health-promoting functions of EGCG, including anti-oxidant, anti-inflammatory, antiatherogenic, and anti-cancer effects have been demonstrated. (Mereles and Hunstein 2011). Previous studies revealed that EGCG could inhibited various intracellular signal transduction pathways mediated by $\mathrm{NF}-\kappa \mathrm{B}$, epidermal growth factor receptor (EGFR), insulin-like growth factor-I (IGF-I) and mitogen-activated protein kinases
(MAPKs) (Khan et al. 2006). EGCG has also shown therapeutic potential in diabetic nephropathy. EGCG has attenuated AGE-induced cytokine synthesis in human embryonic kidney cells (Liang et al. 2010), and decreased RAGE and NF- $\kappa \mathrm{B}$ expression and pathological changes in the kidney tissue of rats with subtotal nephrectomy plus streptozotocin (STZ) injection (Yamabe et al. 2006).

Alpha-lipoic acid (ALA) is a natural occurring dithiol compound that can be found in animal food such as meat and liver (Kataoka 1998). ALA was discovered in 1951 as a molecule that assists in acyl-group transfer and acts as a coenzyme in the Krebs cycle. In addition to eliminating peroxide, ALA is a powerful lipophilic anti-oxidant both in vitro and in vivo (Packer et al. 1997). ALA can interact with other anti-oxidants, such as vitamins $\mathrm{C}$ and $\mathrm{E}$, and strengthen their anti-oxidation abilities. ALA is now used as a dietary supplement for treating aging, diabetes mellitus, and vascular, and neurodegenerative diseases (Yilmaz et al. 2002).

This study will examine the effects of ALA and EGCG in hyperglycemia-induced inflammation and oxidative stress in kidney cells. Furthermore, the hypothesis that ALA augments the anti-oxidant effects of EGCG will be tested.

\section{MATERIALS AND METHODS}

\section{Cell Culture and Reagents}

Human embryonic kidney 293 (HEK293) cells were cultured in Dulbecco's modified eagle medium (DMEM) from Gibco (Grand Island, NY) containing $10 \%$ fetal bovine serum, $100 \mu \mathrm{g} / \mathrm{mL}$ penicillin, and $100 \mu \mathrm{g} / \mathrm{mL}$ streptomycin. Cultures were subcultured on reaching $80 \%$ confluence, using $0.05 \%$ trypsin/ EDTA (Gibco, Grand Island, NY) and the media were changed every two days. The experiments were performed after 2-4 passages. The effects of ALA ( $8 \mathrm{mM})$ and EGCG (2.2 mM) were evaluated by treating HEK 293 before exposure to high glucose concentrations $(25 \mathrm{mM})$. 
MEASUREMENT OF TUMOR NECROSIS FACTOR- $\alpha($ TNF- $\alpha)$

AND INTERLEUKIN-6 (IL-6)

The cells were treated with high glucose for 18 $\mathrm{h}$ with or without EGCG and ALA. The TNF- $\alpha$ and IL-6 levels in cell supernatants were measured by enzyme-linked immunosorbent assay (ELISA) kits (Peprotech Inc., Rocky Hill, NJ). Supernatants were diluted in the ratio of 1:30 before assay. The reaction products were measured at $450 \mathrm{~nm}$ with a microplate reader.

RNA ISOLATION AND REVERSE TRANSCRIPTION(RT)

Total cellular RNA was isolated from HEK293 cells using the single-step acid guanidinium thiocyanate/phenol/chloroform extraction method. For reverse transcription, $1 \mu \mathrm{g}$ of RNA was incubated with $200 \mathrm{U}$ of HiScript I reverse transcriptase (Bionovas Biotechnology, Toronto, Canada) in a buffer containing a final concentration of $20 \mathrm{mmol} / \mathrm{L}$ Tris/HCl (pH 7.8), $100 \mathrm{mmol} / \mathrm{L}$ $\mathrm{NaCl}, 0.1 \mathrm{mmol} / \mathrm{L}$ EDTA, $1 \mathrm{mmol} / \mathrm{L}$ DTT, 50\% glycerol, $2.5 \mu \mathrm{mol} / \mathrm{L}$ poly $(\mathrm{dT})_{12-18}$ oligomer, and $0.5 \mathrm{mmol} / \mathrm{L}$ of each dNTP at a final volume of 20 $\mu \mathrm{L}$. The reaction mixture was incubated at $45^{\circ} \mathrm{C}$ for $1 \mathrm{~h}$ and then at $70^{\circ} \mathrm{C}$ for $15 \mathrm{~min}$ to inactivate the enzyme. The produced cDNA was used to generate DNA product by polymerase chain reaction (PCR).

\section{REAL-TIME PCR}

The cDNA had a 10-fold dilution in nuclease-free water and was used for the Smart Quant Green Master Mix (Protech Technology Enterprise Co., Taipei, Taiwan): $2 \mu \mathrm{L}$ of cDNA solution, 0.5 $\mu \mathrm{mol} / \mathrm{L}$ primers, $5 \mathrm{mmol} / \mathrm{L}$ magnesium chloride, and $2 \mu \mathrm{L}$ of Master SYBR-Green in nuclease-free water with a final volume of $20 \mu \mathrm{L}$. The primers used for PCR were:

RAGE: forward, 5'AAGCCCCTGGTGCCTAATGAG3'; reverse, 5'CACCAATTGGACCTCCTCCA3'.

GAPDH: forward, 5'CGACCACTTTGTCAAGCTCA3'; reverse, 5'AGGGGTCTACATGGCAACTG3'.
The initial denaturizing phase was $5 \mathrm{~min}$ at $95{ }^{\circ} \mathrm{C}$ followed by an amplification phase as detailed below: denaturation at $95{ }^{\circ} \mathrm{C}$ for $10 \mathrm{sec}$; annealing at $55^{\circ} \mathrm{C}$ for $10 \mathrm{sec}$; elongation at $72{ }^{\circ} \mathrm{C}$ for $15 \mathrm{sec}$ and detection at $79^{\circ} \mathrm{C}$ for 45 cycles. Amplification, fluorescence detection, and postprocessing calculation were performed using the ABI step1 apparatus. Individual PCR product was analyzed for DNA sequence to confirm the purity of the product.

\section{WESTERN BLOT ANANLYSIS}

Total protein samples were mixed with sample buffer, boiled for 5 minutes, separated by $10 \%$ SDSPAGE under denaturing conditions, and electroblotted to nitrocellulose membranes (Amersham Pharmacia Biotech, CB, UK). The nitrocellulose membranes were blocked in blocking buffer, incubated with human anti-RAGE (Santa Cruz Biotechnology Inc., CA) antibodies, washed, and incubated with horseradish peroxidase-conjugated secondary antibodies. Signals were visualized by enhance chemiluminescent detection.

\section{OXIDATIVE STRESS TEST}

The cells were treated with high glucose concentrations for $18 \mathrm{~h}$ with or without EGCG and ALA. The levels of superoxide dismutase (SOD) activity in cell supernatants were measured using SOD assay kit (catalog no. 706002, Cayman Chemical, Ann Arbor, MI). Supernatants were diluted in the ratio of 1:30 before assay. The reaction products were measured at $440-460 \mathrm{~nm}$ with a microplate reader.

\section{STATISTICAL ANALYSIS}

The data were expressed as mean \pm SEM. A Tukey test was used for comparing parametric variables between the two groups, while ANOVA with repeat measurement design was used for time-course changes. Statistical significance was evaluated by Tukey test (GraphPad Software Inc., 
San Diego, CA). A p-value of less than 0.05 was considered statistically significant.

\section{RESULT}

EGCG AND ALA INHIBITS TNF- $\alpha$ AND IL-6 PRODUCTION

High concentration glucose has been found to stimulate inflammatory reaction in glomerular cells. In our experiments, high-concentration glucose increased TNF- $\alpha$ (Figure. 1A) and IL-6 (Figure. 1B) production in HEK293T cells. Both EGCG alone and EGCG combined with ALA (EA) significantly inhibited high glucose-induced TNF- $\alpha$ and IL-6 secretion in the culture medium. The combination of EGCG and ALA showed greater effect than EGCG alone. However, the effect of ALA alone was not significant.

ANTI-OXIDANTS INHIBIT THE EXPRESSION OF RAGE

RAGE is a key factor in diabetic nephropathy. We examined the effects of EGCG, ALA, and EA against glucose-induced RAGE up-regulation. As shown in Figure 2, high-concentration glucose significantly induced RAGE mRNA expression in HEK293T cells. Both EGCG and ALA significantly attenuated high glucose-induced RAGE mRNA expression. The combination of EGCG and ALA showed greater effect than EGCG alone. RAGE protein expression in HEK cells was also significantly attenuated by being treated with EGCG, ALA, and EA (Figure. 3). Similar to the findings in RAGE mRNA experiments, the combination of EGCG and ALA showed greater effect than EGCG alone. These findings indicate that both EGCG and ALA may inhibit glucose-induced inflammation in kidney cells through decreasing RAGE expression and that ALA augments the effect of EGCG.

\section{EFFECTS OF EGCG ON GLUCOSE-INDUCED INCREASE IN}

\section{OXIDATIVE STRESS}

To evaluate the effects of EGCG and ALA on hyperglycemia-induced oxidative stress, we examined the activity of SOD and ROS at various levels in HEK293T cells with or without
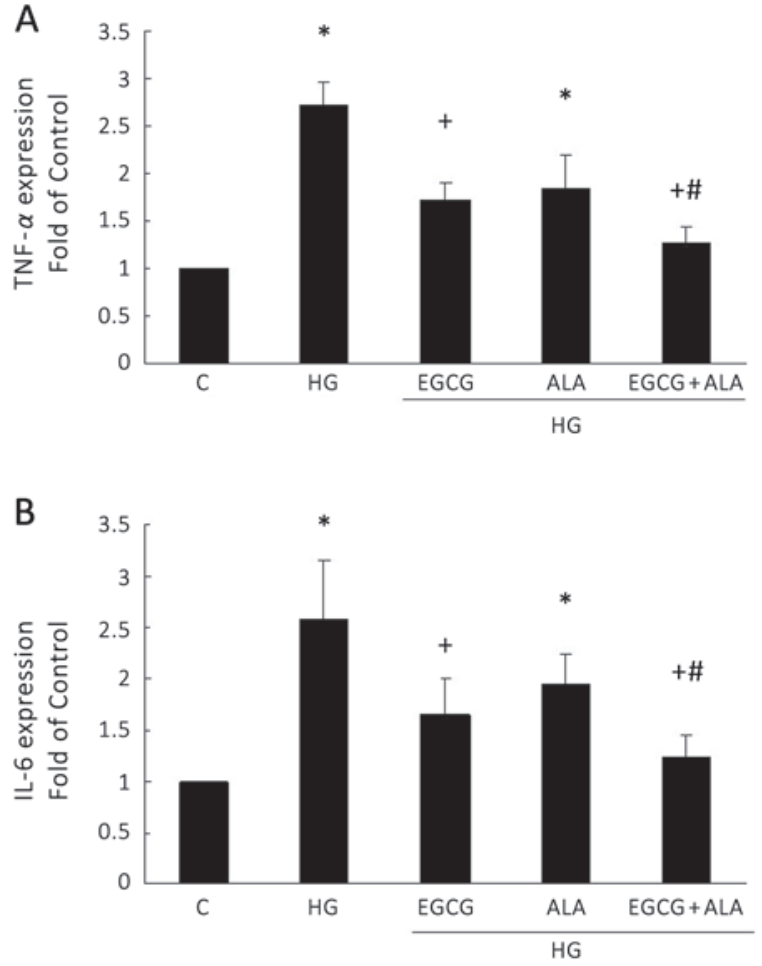

Figure 1 - EGCG and EGCG combined with ALA attenuated high glucose(HG)-induced TNF- $\alpha$ and IL-6 secretion from HEK cells. ELISA was used to measure the TNF- $\alpha(\mathbf{A})$ and IL-6 (B) expression in supernatants of cell culture. High glucose increased the amount of TNF- $\alpha$ and IL-6. Pre-treatment with EGCG (2.2 mM) significantly attenuated high glucoseinduced TNF- $\alpha$ and $I L-6$ in HEK cells. The combination of EGCG and ALA showed more effect than EGCG alone. The effect of ALA ( $8 \mathrm{mM})$ alone was not significant. *p $<0.01$ versus control; $+\mathrm{p}<0.05$ when compared to high glucose group.; $\# \mathrm{p}<0.05$ when compared to EGCG group.

treatment. As shown in Figure 4, HEK293T cells exposed to high concentration glucose had decreased SOD activity. However, EGCG, ALA, and EA significantly recovered SOD activity in HEK293T cells in a high glucose environment. High-glucose incubation significantly increased ROS, EGCG, ALA, and EA significantly decreased high glucose-induced ROS (Figure. 4). The combination of EGCG and ALA showed greater effect than EGCG alone. These findings suggest that EGCG, ALA, and EA inhibit hyperglycemiainduced oxidative stress in HEK293T cells and that ALA augments the effect of EGCG. 


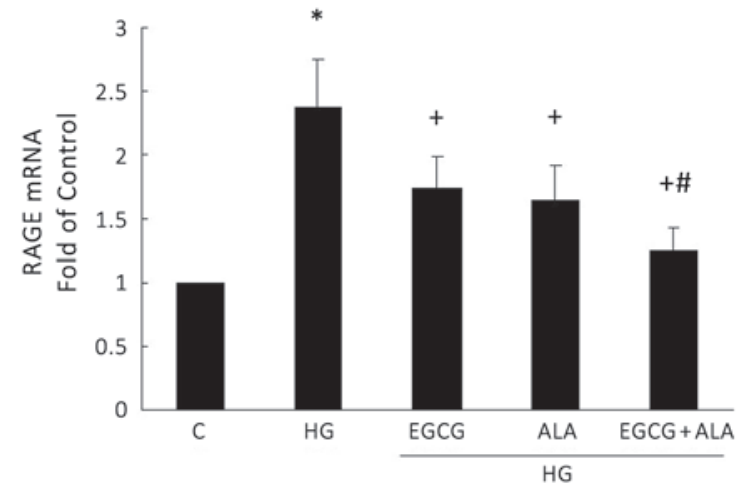

Figure 2 - EGCG and ALA attenuated high glucose(HG)induced expression of RAGE mRNA in HEK cells. Pretreatment with EGCG $(2.2 \mathrm{mM})$ and/or ALA $(8 \mathrm{mM})$ significantly attenuated high glucose-induced RAGE mRNA expression. The combination of EGCG and ALA showed more effect than EGCG alone. Total RNA was extracted and real-time PCR was performed. ${ }^{*} \mathrm{p}<0.01$ versus control; $+\mathrm{p}<0.05$ when compared to high glucose group; $\# \mathrm{p}<0.05$ when compared to EGCG group.
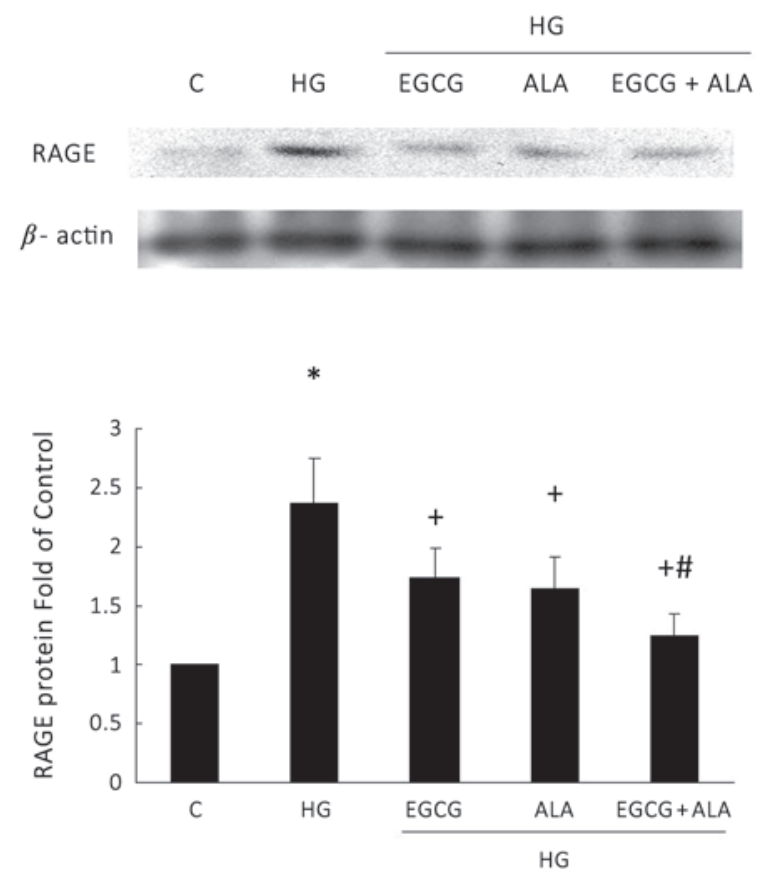

Figure 3 - EGCG and ALA attenuated high glucose(HG)induced RAGE protein expression in HEK cells. Pre-treatment with EGCG $(2.2 \mathrm{mM})$ and/or ALA $(8 \mathrm{mM})$ significantly attenuated high glucose(HG)-induced RAGE protein expression. The combination of EGCG and ALA showed more effect than EGCG alone. * $\mathrm{p}<0.01$ versus control; $+\mathrm{p}<$ 0.05 when compared to high glucose group ; $\# \mathrm{p}<0.05$ when compared to EGCG group.
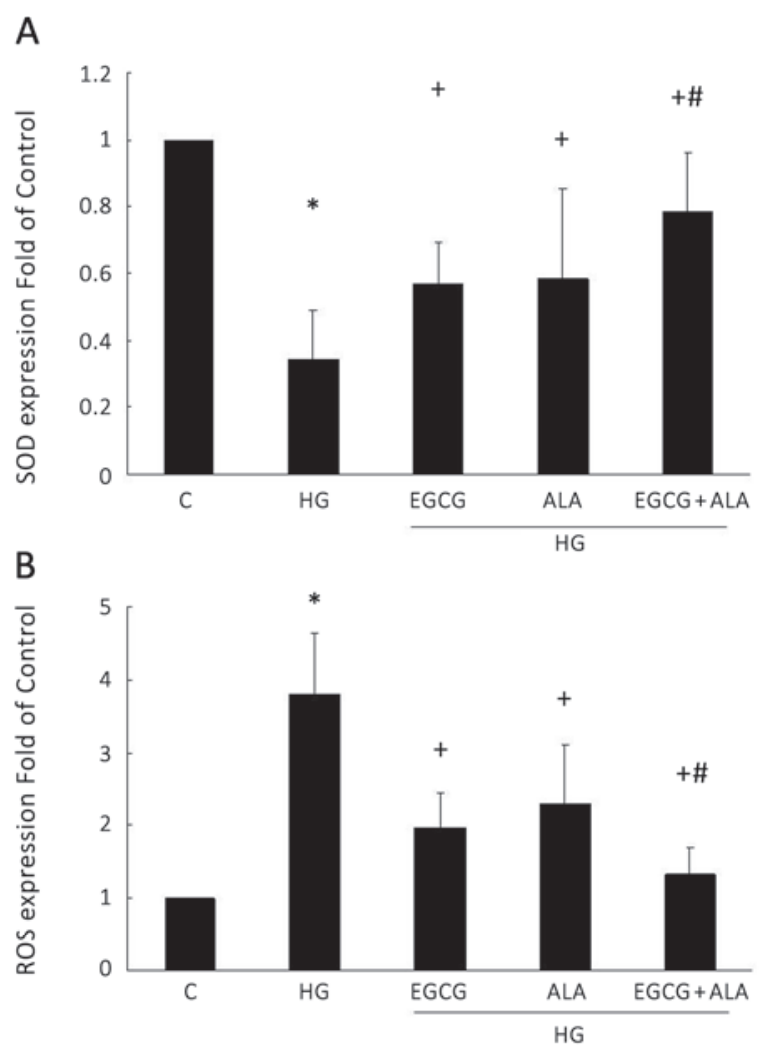

Figure 4 - (A) Effects of EGCG and ALA on high glucosedecreased superoxide dismutase (SOD) activity in HEK cells. Cellular SOD activity was revealed by SOD assay kit. Both EGCG $(2.2 \mathrm{mM})$ and ALA $(8 \mathrm{mM})$ significantly reversed high glucose-decreased SOD expression. The combination of EGCG and ALA showed more effect than EGCG alone. (B) The inhibitory effect of EGCG and ALA on high glucoseinduced ROS expression. Both EGCG (2.2 mM) and ALA (8 $\mathrm{mM}$ ) significantly decreased the high-glucose-induced ROS expression in HEK cells. The combination of EGCG and ALA showed more effect than EGCG alone. ${ }^{*} \mathrm{p}<0.01$ versus control; $+\mathrm{p}<0.05$ when compared to high glucose group; \# $\mathrm{p}$ $<0.05$ when compared to EGCG group.

\section{DISCUSSION}

Diabetic nephropathy is the most common cause of end-stage renal disease. Various hyperglycemiainduced metabolic substances, including AGEs, protein kinase $\mathrm{C}$ (PKC), and AT-II were considered to contribute to the progression of diabetic nephropathy (Yamagishi and Imaizumi 2005). However, recent studies showed that intensive blood glucose control may better prevent long-term kidney damage (de Boer et al. 2011, Holman et al. 2008). Although the 
exact mechanism responsible for hyperglycemiainduced kidney damage is still under investigation, accumulated evidence indicates that AGE-RAGE oxidative stress may be the main pathologic pathway for diabetic nephropathy (Yamagishi 2011). The possible mechanism of RAGE-mediated inflammation was evaluated in previous studies (Yan et al. 2010). Hyperglycemia causes AGE accumulation and RAGE activation, followed by increased production of extracellular ROS. Increased ROS stimulates the production of AGEs and non-AGE ligands of RAGE. These ligands and ROS stimulate RAGE, increase intracellular NF- $\kappa \mathrm{B}$ production, and induce production of inflammatory substances. In our study, EGCG and ALA decreased high glucose-induced RAGE expression. ALA also augmented the RAGE-inhibiting effect of EGCG in HEK cells. Previous studies showed that ALA regenerated vitamins $C$ and $E$ from their oxidized forms and augmented their anti-oxidant activity (Kozlov et al. 1999). This is the first study to identify the synergism of EGCG and ALA in kidney cells.

The role of ROS in RAGE-mediated inflammation was also shown in other studies (Yao and Brownlee 2010). Hyperglycemia induces intracellular ROS production by the mitochondrial electron transport chain, and increases expression of RAGE and endogenous RAGE ligands in human aortic endothelial cells. This increase in RAGE can be suppressed by overexpression of superoxide dismutase 2 (SOD2) or by the application of a superoxide dismutase mimetic compound. Oxidative stress and superoxide are causes of diabetic complications. SOD is the major anti-oxidant enzyme for superoxide removal, which converts superoxide into hydrogen peroxide and molecular oxygen (Miao and St Clair 2009). In a study of non-insulin-dependent diabetes, the SOD activity in erythrocytes was higher in patients without nephropathy than in patients with nephropathy (Kedziora-Kornatowska et al. 1998). Overexpression of SOD genes in transgenic mice attenuated the pathological progression of diabetic nephropathy (DeRubertis et al. 2004). Recent studies also showed that kidney SOD was lower in diabetic mice than in control mice (Fujita et al. 2009). AT-II was thought to increase oxidative stress by enhancing production of reactive oxygen species. An AT-II receptor blocker, telmisartan, was shown to increase left ventricle SOD levels in diabetic rats (Goyal et al. 2011). These results indicated that oxidative stress is a major pathological factor for kidney damage in patients with diabetic nephropathy. Anti-oxidative agents are going to be the new research targets for drug development. This study demonstrated that EGCG and ALA significantly decreased the oxidative stress.

Few papers have studied the effect of EGCG on RAGE expression and oxidative stress activation. EGCG was shown to attenuate AGEs-induced RAGE expression in human kidney (Liang et al. 2010) and human neuroblastoma cells (Lee and Lee 2007), decrease oxidative stress and serum creatinine in a mouse model of immune-mediated glomerulonephritis (Peng et al. 2011), and reduce chemotherapyinduced TNF- $\alpha$ up-regulation and oxidant stress signals in mouse kidneys (El-Mowafy et al. 2010). Oxygen free radicals are important mediators in the pathogenesis of arthritis as they increase proinflammatory cytokine expression. EGCG was shown to remove ROS and increase anti-oxidant enzymes, such as catalase, superoxide dismutase, and glutathione peroxidase (Singh et al. 2010). In our study, EGCG was shown to inhibit hyperglycemiainduced RAGE, ROS, TNF- $\alpha$, and IL-6 expression. Furthermore, ALA augmented the anti-oxida oxidant effects of EGCG in kidney cells. Anti-oxidants may serve as a potential therapy for attenuating kidney function decline in diabetic patients.

Many clinical studies were done to evaluate therapeutic effects of EGCG in patients with cancers (Singh et al. 2011), hyperlipidemia, or diabetes mellitus (Wolfram 2007). The usual dosages were between 200 and $600 \mathrm{mg}$ daily. Few adverse effects were noted (Chen et al. 2011). In a phase II trial of green tea for patients with androgen independent 
metastatic prostate carcinoma, six grams of green tea were administrated orally per day. Adverse effects were observed in $69 \%$ of patients and included nausea, emesis, insomnia, fatigue, diarrhea, abdominal pain, and confusion (Jatoi et al. 2003).

The therapeutic effect of ALA supplementation in diabetic patients was also studied in many previous trials (Singh and Jialal 2008). ALA efficiently decreased endothelial damage, vascular dysfunction, oxidative stress, and polyneuropathies in patients with type 1 and 2 diabetes. ALA also increased insulin sensitivity and improved glycemic control. The usual daily oral dosages of ALA were between 600 and 1,800 mg (Golbidi et al. 2011). Few adverse effects were noted in previous trials. At higher doses, gastrointestinal symptoms, such as abdominal pain, nausea, vomiting, and diarrhea, and skin allergic reactions had been reported (Ziegler et al. 2006).

The synergistic effects of hypoglycemic agents and anti-oxidants in preventing the progress of diabetic nephropathy in human subjects need further evaluation. Our study may provide cues for designing new anti-oxidant-based drugs for therapeutic purposes.

\section{ACKNOWLEDGMENTS}

This study was partially supported with grants from the Shin Kong Wu Ho-Su Memorial Hospital, Taipei, Taiwan (SKH-8302-101-DR-04).

\section{RESUMO}

Os efeitos antioxidantes de galato de epigalocatequina (EGCG) e ácido alfa lipóico (ALA) foram demonstrados em estudos anteriores. Os efeitos renais da proteção de EGCG e ALA em pacientes com lesão renal ainda estão sob investigação. A finalidade deste estudo é investigar os efeitos anti-inflamatórios e antioxidantes de EGCG e ALA em lesão de células de rim humano induzida pela alta glicose. EGCG inibiu a produção de TNF- $\alpha$ e IL-6 induzida por $\mathrm{HG}$ em células de rim embrionário humano (HEK). Ambos EGCG e ALA diminuíram o mRNA do receptor de produtos finais de glicação avançada (RAGE) induzida por HG e a expressão de proteínas em células HEK. EGCG e ALA também recuperaram a produção de superóxido dismutase inibida por HG e diminuíram a expressão de ROS em células HEK. O sinergismo de EGCG e ALA também foi estudado. O efeito de EGCG combinado com ALA é maior do que o efeito de EGCG sozinho em todos os experimentos anti-inflamatórios e antioxidantes. Os nossos estudos fornecem uma potencial aplicação terapêutica do EGCG e ALA na prevenção da progressão de nefropatia diabética.

Palavras-chave: nefropatia diabética, receptores de produtos finais da glicação avançada, epigalocatequina galato, ácido alfa-lipóico, antioxidante.

\section{REFERENCES}

Ansari A, Thomas S AND Goldsmith D. 2003. Assessing glycemic control in patients with diabetes and end-stage renal failure. Am J Kidney Dis 41: 523-531.

Bohlender JM, Franke S, Stein G and Wolf G. 2005. Advanced glycation end products and the kidney. Am J Physiol Renal Physiol 289: F645-659.

Chen D, WAN SB, YANG H, YuAn J, CHAN TH AND Dou QP. 2011. EGCG, green tea polyphenols and their synthetic analogs and prodrugs for human cancer prevention and treatment. Adv Clin Chem 53: 155-177.

De Boer IH, Sun W, Cleary PA, Lachin JM, Molitch ME, STEFFES MW AND ZINMAN B. 2011. Intensive diabetes therapy and glomerular filtration rate in type 1 diabetes. N Engl J Med 365: 2366-2376.

DeRubertis FR, Craven PA, Melhem MF and Salah EM. 2004. Attenuation of renal injury in $\mathrm{db} / \mathrm{db}$ mice overexpressing superoxide dismutase: evidence for reduced superoxide-nitric oxide interaction. Diabetes 53: 762-768.

EL-Mowafy AM, Al-Gayyar MM, SALEM HA, El-Mesery ME AND DARWEISH MM. 2010. Novel chemotherapeutic and renal protective effects for the green tea (EGCG): role of oxidative stress and inflammatory-cytokine signaling. Phytomedicine 17: 1067-1075.

Fujita H, Fujishima H, ChidA S, TAKAHASHi K, QI Z, KANETSUNA Y, BREYER MD, HARRIS RC, YAMADA Y AND TAKAHASHI T. 2009. Reduction of renal superoxide dismutase in progressive diabetic nephropathy. J Am Soc Nephrol 20: 1303-1313.

Giugliano D, Ceriello A And Paolisso G. 1996. Oxidative stress and diabetic vascular complications. Diabetes Care 19: 257-267.

GOLBIDI S, BADRAN AND LAHER I. 2011. Diabetes and alpha lipoic Acid. Front Pharmacol 2: 69.

Goyal BR, Parmar K, Goyal RK And Mehta AA. 2011. Beneficial role of telmisartan on cardiovascular complications associated with STZ-induced type 2 diabetes in rats. Pharmacol Rep 63: 956-966. 
HOLMAN RR, PAUL SK, BETHEL MA, MATTHEWS DR AND NEIL HA. 2008. 10-year follow-up of intensive glucose control in type 2 diabetes. N Engl J Med 359: 1577-1589.

Jatoi A, Ellison N, Burch PA, SloAN JA, DAKHIL SR, NOVOYNY P, TAN W, FITCH TR, ROWLAND KM, YOUNG CY AND FLYNN PJ. 2003. A phase II trial of green tea in the treatment of patients with androgen independent metastatic prostate carcinoma. Cancer 97: 1442-1446.

JIAO B, WANG YS, CHENG YN, GAO JJ AND ZHANG QZ. 2011. Valsartan attenuated oxidative stress, decreased MCP-1 and TGF-beta1 expression in glomerular mesangial and epithelial cells induced by high-glucose levels. Biosci Trends 5: 173-181.

KATAOKA H. 1998. Chromatographic analysis of lipoic acid and related compounds. J Chromatogr B Biomed Sci Appl 717: 247-262.

KEDZIORA-KORNATOWSKA KZ, LUCIAK M, BLASZCZYK J AND PAWLAK W. 1998. Lipid peroxidation and activities of antioxidant enzymes in erythrocytes of patients with non-insulin dependent diabetes with or without diabetic nephropathy. Nephrol Dial Transplant 13: 2829-2832.

Khan N, Afaq F, SaleEm M, Ahmad N and Mukhtar H. 2006. Targeting multiple signaling pathways by green tea polyphenol (-)-epigallocatechin-3-gallate. Cancer Res 66: 2500-2505.

Kozlov AV, Gille L, STANiEK K AND NOHL H. 1999. Dihydrolipoic acid maintains ubiquinone in the antioxidant active form by two-electron reduction of ubiquinone and one-electron reduction of ubisemiquinone. Arch Biochem Biophys 363:148-154.

LEE SJ AND LEE KW. 2007. Protective effect of (-)-epigallocatechin gallate against advanced glycation endproductsinduced injury in neuronal cells. Biol Pharm Bull 30: $1369-1373$

Liang YJ, Jian JH, LiU YC, JUANG SJ, SHyU KG, LAi LP, WANG BW AND LEU JG. 2010. Advanced glycation end products-induced apoptosis attenuated by PPARdelta activation and epigallocatechin gallate through NF-kappaB pathway in human embryonic kidney cells and human mesangial cells. Diabetes Metab Res Rev 26: 406-416.

Mauer SM, StefFes MW, Ellis EN, Sutherland DE, BROWN DM AND GOETZ FC. 1984. Structural-functional relationships in diabetic nephropathy. J Clin Invest 74: $1143-1155$

MERELES D AND HUNSTEIN W. 2011. Epigallocatechin3-gallate (EGCG) for Clinical Trials: More Pitfalls than Promises? Int J Mol Sci 12: 5592-5603.

MiaO L AND ST Clair DK. 2009. Regulation of superoxide dismutase genes: implications in disease. Free Radic Biol Med 47: 344-356.

Packer L, Tritschler HJ AND Wessel K. 1997. Neuroprotection by the metabolic antioxidant alpha-lipoic acid Free Radic Biol Med 22: 359-378.

Peng A, Ye T, Rakheja D, Tu Y, Wang T, Du Y, Zhou JK, VAZIRI ND, HuZ, MOHANCANDZHOU XJ.2011. The green tea polyphenol (-)-epigallocatechin-3-gallate ameliorates experimental immune-mediated glomerulonephritis. Kidney Int 80: 601-611.
SinGH BN, SHANKAR S AND SRIVASTAVA RK. 2011. Green tea catechin, epigallocatechin-3-gallate (EGCG): mechanisms, perspectives and clinical applications. Biochem Pharmacol 82: 1807-1821.

Singh R, AKhtaR N AND HaQQI TM. 2010. Green tea polyphenol epigallocatechin-3-gallate: inflammation and arthritis. [corrected]. Life Sci 86: 907-918.

SINGH U AND Jialal I. 2008. Alpha-lipoic acid supplementation and diabetes. Nutr Rev 66: 646-657.

Sourris KC, Harcourt BE, PENFOLd SA, YAP FY, Morley AL, Morgan PE, DaVIES MJ, BAKER ST, JERUMS G AND FORBES JM. 2010. Modulation of the cellular expression of circulating advanced glycation end-product receptors in type 2 diabetic nephropathy. Exp Diabetes Res 2010: 974681.

WATANABE K ET AL. 2010. Role of differential signaling pathways and oxidative stress in diabetic cardiomyopathy. Curr Cardiol Rev 6: 280-290.

WOLFRAM S. 2007. Effects of green tea and EGCG on cardiovascular and metabolic health. J Am Coll Nutr 26: 373S-388S

YAMABE N, YOKOZAWA T, OYA T AND KiM M. 2006. Therapeutic potential of (-)-epigallocatechin 3-O-gallate on renal damage in diabetic nephropathy model rats. $\mathrm{J}$ Pharmacol Exp Ther 319: 228-236.

YAMAGISHI S. 2011. Role of advanced glycation end products (AGEs) and receptor for AGEs (RAGE) in vascular damage in diabetes. Exp Gerontol 46: 217-224.

YAMAGISHI S AND IMAIZUMI T. 2005. Diabetic vascular complications: pathophysiology, biochemical basis and potential therapeutic strategy. Curr Pharm Des 11: 2279-2299.

YAMAGishi S AND MATSUI T. 2010. Advanced glycation end products, oxidative stress and diabetic nephropathy. Oxid Med Cell Longev 3: 101-108.

YAN SD, SCHMidT AM, ANDERson GM, Zhang J, BRETT J, ZOU YS, PINSKY D AND STERN D. 1994. Enhanced cellular oxidant stress by the interaction of advanced glycation end products with their receptors/binding proteins. J Biol Chem 269: 9889-9897.

YAN SF, RAMASAMY R AND SCHMIDT AM. 2010. The RAGE axis: a fundamental mechanism signaling danger to the vulnerable vasculature. Circ Res 106: 842-853.

YanG H, JIN X, KeI LAM CW AND Yan SK. 2011. Oxidative stress and diabetes mellitus. Clin Chem Lab Med 49: 1773-1782.

YAO D AND BROWNLEE M. 2010. Hyperglycemia-induced reactive oxygen species increase expression of the receptor for advanced glycation end products (RAGE) and RAGE ligands. Diabetes 59: 249-255.

YILMAZ O, OZKAN Y, YILDIRIM M, OZTURK AI AND ERSAN Y. 2002. Effects of alpha lipoic acid, ascorbic acid-6palmitate, and fish oil on the glutathione, malonaldehyde, and fatty acids levels in erythrocytes of streptozotocin induced diabetic male rats. J Cell Biochem 86: 530-539.

ZIEGLER D ET AL. 2006. Oral treatment with alpha-lipoic acid improves symptomatic diabetic polyneuropathy: the SYDNEY 2 trial. Diabetes Care 29: 2365-2370. 